\title{
Antiviral Effects of the Liquid Culture, Cell Free Supernatants and Extracellular Products from Serratia marcescens subsp. marcescens against Watermelon Mosaic Virus (WMV)
}

\author{
Seham Abd El-Shafi and S. A. M. Mahgoub* \\ Botany Department, Faculty of Science and *Microbiology \\ Department, Faculty of Agriculture, Zagazig University, \\ Zagazig, Egypt.
}

\begin{abstract}
7 TIS STUDY was to specify the potential antiviral action of Serratia marcescens subsp. marcescens and its extracellular products against watermelon mosaic virus (WMV). The highest level of protection observed occurred in experiments, where bacteria were mixed with virus in vitro before inoculation, resulting in gave $100 \%$ viral inhibition. S. marcescens significantly improved $(p<0.05)$ several growth parameters in all experiments compared to viral control. The highest level of virus inhibition obtained when a mixture of all compounds extracted and purified from $S$. marcescens subsp. marcescens was applied to cucumber plants reducing infection by $95 \%$. The results of RT-PCR showed that in vitro liquid bacterial culture treatment and applied $24 \mathrm{hr}$ after virus inoculation treatment highly reduced the accumulation of WMV in treated plant leaves. The usage of $S$. marcescens in vitro and in vivo led to increase in total protein, polyphenoloxidase and phenolic compounds compared to viral-infected and healthy controls, while reducing glutathione oxidase. $S$. marcescens, and its metabolic products found in culture filtrates show promise as an effective biocontrol agent for WMV infection in plants and appear to promote plant growth even in the absence of virus.
\end{abstract}

Keywords: Serratia, Watermelon mosaic virus, Systemic and local resistance, RT-PCR, Antioxidant enzymes

Viruses affecting plant health are chronic threats to food production and ecosystem stability worldwide. Viruses affect many economically important crops: tomato mottle virus infects tomato (Murphy \& Zehnder, 2000) while cucumber mosaic virus (CMV) infects over 800 plants species (Palukaitis et al., 1992). Zucchini yellow mosaic virus (ZYMV) infects cucumber (Abd El- Shafi, 2005) and watermelon mosaic virus (WMV) naturally infects members of Cucurbitaceae, Chenopodiaceae, Malvaceae \& Legumonsae families (Shukla et al., 1994).

Watermelon mosaic virus (WMV) is a member of genus Potyvirus (family: Potyviridae) and consists of flexuous, filamentous particles, approximately $750 \mathrm{~nm}$ long. WMV can experimentally infect more than 170 plant species belonging to 27 families, including many weeds that can host the virus between crops (Desbiez 
et al., 2007). Watermelon mosaic virus-1 (WMV-1) is synonymous with papaya ring spot virus strain W (Purcifull et al., 1984). It was first reported in India by Bharagava and Joshi in 1960 (Sharma et al., 2010). Watermelon mosaic virus (WMV) [formerly watermelon mosaic virus-2] was first described by Webb \& Scott (1965). WMV causes mosaic patches on foliage and fruits of infected plants. The plants are especially damaged when infected as young plants because the yields are reduced and the fruit quality is often affected by bumps and discoloration (Hausbeck, 2011).

Host defenses in plants can be stimulated by various means, including plant extracts, synthetic chemicals and rhizobacteria. Nonpathogenic rhizobacteria can induce protection against a wide variety of pathogens, a process known as induced systemic resistance. Among Serratia species, S. marcescens subsp. marcescens is an important bacterium which induces systemic resistance to various pathogens. The strain $S$. marcescens $90-166$ protects plants against cucumber mosaic virus (Raupach et al., 1995 and Ryu et al., 2004). Serratia marcescens (a Gram-negative bacterium, Enterobacteriaceae, soil inhabitant) produces a variety of chitinolytic enzymes, DNAase, lipase and gelatinase (Ulhoq \& Peberdy, 1991 and Giri et al., 2004). S. marcescens subsp. marcescens was considered originally to be an innocuous, non-pathogen and was used as a biological marker. The ability to form red pigment (prodigiosin) is characteristics of it (Hejazi\& Falkiner, 1997).

The objective of the present study was to specify the potential antiviral action of Serratia marcescens subsp. marcescens and its extracellular products against WMV.

\section{Materials and Methods}

Bacteria and Virus

The plant growth promoting bacteria Serratia marcescens subsp. marcescens was isolated from Sharkia Governorate, Egypt and identified according to Bergy's Manual systematic of bacteriology. A total of 50 presumptive Serratia isolates which produced red pigments were isolated from the different soil samples using nutrient agar (Difco Manual, 1994). Subsequent confirmation using biochemical tests showed that $95 \%$ of the isolates had the typical morphology and biochemical reactions expected of $S$. marcescens. The cultures were stored in glycerol $(20 \%)$ at $-20{ }^{\circ} \mathrm{C}$ in the research collection of the Laboratory of Microbiology, Faculty of Agriculture, Zagazig University, Zagazig, Egypt. The identification was confirmed in the Egyptian culture collection at Cairo Mercin, Ain Shams University, Cairo. The cultures of $S$. marcescens were maintained on nutrient agar slopes at $4{ }^{\circ} \mathrm{C}$ and subcultured every 4 weeks. Aliquots $(100 \mu \mathrm{l})$ of fresh culture of $S$. marcescens was inoculated into Erlenmeyer flasks, $250 \mathrm{ml}$ capacity, each containing $100 \mathrm{ml}$ of nutrient broth $\mathrm{pH} 7$ and incubated at $37{ }^{\circ} \mathrm{C}$ in a shaking incubator at $150 \mathrm{rpm}$ for 3 days for producing sufficient inoculum. A final inoculum was prepared by serially dilutions in Ringer's solution to reach a final level of $7 \log \mathrm{CFU} \mathrm{ml}{ }^{-1}$ as determined by optical density at $600 \mathrm{~nm}$ and confirmed by plate counting on nutrient agar. The cell free supernatant (CFS) was then prepared by filtration through a $0.45 \mu \mathrm{m}$ filter. The filtrate obtained and the

Egypt. J. Microbiol. 47 (2012) 
liquid culture were both used for antiviral assays. Watermelon mosaic virus (WMV-Egyptian isolate) used in all the experiments was isolated from naturally infected squash fruit. This virus was identified based on the external symptoms on naturally infected squash fruit; on symptoms of mechanically infected cucumber plants and on real time- polymerase chain reaction (RT-PCR) analysis. The seeds of Cucumis sativus L. cultivar Beit Alpha F-1 were obtained from Agriculture Research Institute, Giza, Egypt and used as viral host plants. A fertile cultivated soil was obtained from Sharkia Governorate for cultivation of cucumber seeds in plastic pots $\left(1000 \mathrm{~cm}^{3}\right)$ one $\mathrm{cm}$ depth below the soil surface and kept under the natural day light in the greenhouse of Faculty of Science, Zagazig University. Irrigation of cultivated seeds was carried out as required until the end of each experiment. The virus was propagated and maintained in cucumber plants according to Faccioli \& Capponi (1983): $5 \mathrm{~g}$ of naturally infected zucchini fruits were ground in a sterile mortar with a pestle in $5 \mathrm{ml}$ of $0.01 \mathrm{M}$ phosphate buffer solution of $\mathrm{pH} 7.2$ then filtered through cotton. The volume was made up to $20 \mathrm{ml}$ with phosphate buffer then $100 \mu \mathrm{l}$ of viral sap were mechanically inoculated into coteledonary leaves and first leaf of squash dusted by carborundum (600 mesh-Prolab). The inoculated leaves were then washed with distilled water (Yarwood, 1955). After 28 days the symptoms were recorded and the infected leaves were frozen and used as a source of inocula in further experiments.

\section{Antiviral bioassay}

Two experiments were carried out :

Treatment with bacterial culture or CFS against WMV (In vitro)

In this experiment, equal volumes of the liquid bacterial culture or separately CFS and WMV were mixed together $(2 \mathrm{ml}$ of sap containing virus $+2 \mathrm{ml}$ of liquid culture in a test tube for $10 \mathrm{~min}$ and then $100 \mu \mathrm{l}$ of the mixture, inoculated directly into the cotyledonary first leaves of Cucumis sativus L. previously dusted with carborundum (600 mesh, Prolab). The inoculated leaves were then washed with distilled water according to Yarwood (1955). The number of plants with symptoms were counted after 28 days and the mean of 20 plants per each treatment was calculated. General control plants (healthy plants) were inoculated with buffer only. Viral control plants were inoculated with $2 \mathrm{ml}$ buffer $+2 \mathrm{ml}$ viral sap. The percentage of inhibition was calculated according to the equation: $\%$ of viral inhibition $=$ number of symptomatic plants in viral control - number of symptomatic plants in treatment / number of symptomatic plants in viral control $\mathrm{x}$ 100. Plants were harvested and then number of leaves, shoot length and fresh weight were determined.

Post inoculation experiment (treatment after virus infection) (In vivo)

The cotyledonary leaves and first leaf of Cucumis sativus L. plants were inoculated with virus inoculum (100 $\mu \mathrm{l} /$ leaf) after dusting the leaves with carborundum, then the inoculated leaves were washed with distilled water. After 6 and $24 \mathrm{hr}$, the leaves were treated with the liquid bacterial culture or CFS $100 \mathrm{ul} / \mathrm{leaf}$. 
The developing symptoms were recorded after 28 days (20 plants for each treatment) and the percentages of inhibition were calculated as mentioned before. The viral control (cucumber plants inoculated with WMV only) and the general control (healthy plants treated with phosphate buffer) were done. Plants were harvested and then number of leaves, shoot length and fresh weight were determined.

\section{Seed treatment experiment}

The cucumber seeds were soaked in liquid bacterial culture and CFS for 12, 24 and $36 \mathrm{hr}$, then the seeds were germinated in pots. After germination, the cotyledonary leaves and first leaf were dusted by carborundum prior to inoculation with WMV inoculum $(100 \mu \mathrm{l} / \mathrm{leaf})$, after which the inoculated leaves were rinsed with distilled water. The symptoms were observed and recorded up to 28 days from inoculation. The percentages of inhibition were calculated. Healthy control seeds were done by soaking seeds in distilled water for each period. The viral control is cucumber seeds soaked in distilled water for 6, 12 and $24 \mathrm{hr}$, then germinated and mechanically inoculated with virus inoculum only. Plants were harvested and then number of leaves, shoot length and fresh weight were determined.

\section{Antiviral activity of Serratia marcescens subsp. marcescens substances}

Production of sufficient amount of antiviral compounds was carried out according to method described by Abd El-Shafi (2005). S. marcescens was cultured in 20 Erlenmeyer flasks , $250 \mathrm{ml}$ capacity, each containing $100 \mathrm{ml}$ of nutrient broth $\mathrm{pH} 7$, then inoculated and incubated at $37^{\circ} \mathrm{C}$ in a shaking incubator $150 \mathrm{rpm}$ for 3 days. At the expiry of the incubation period, 9 organic solvents, namely: benzene, ethyl alcohol, ethyl acetate, methanol, pentanol, petrolium ether, chloroform, acetone and diethyl ether $(\mathrm{v} / \mathrm{v})$ were tested for their ability to extract antiviral compounds from broth. The extract was obtained by shaking the extracts in a separating funnel 3 times. The organic phase was collected and evaporated under reduced pressure by using a roatary evaporator. The evaporation was continued until less than $5 \mathrm{ml}$ remained. The extract was spotted on thin layer chromatography (TLC) silica gel plates using butanol: acetic acid: water (2:1:1, v: v: v) as the solvent developing system, then examined under UV light revealing and 6 spots (Fig. 1). The $\mathrm{R}_{\mathrm{f}}$ values for the six spots and their antiviral activity were determined. Each spot was separately collected, combined and eluted in chloroform and filtered. The eluate was concentrated till dryness by vacuum rotary evaporation. The dry film of each spot dissolved in $1 \mathrm{ml}$ methanol, then the eluate diluted by adding $5 \mathrm{ml}$ of distilled water. The antiviral activity was carried out after mixing the eluted compounds with sap containing WMV (v: v) and the percent of viral inhibition was calculated after 28 days

Egypt. J. Microbiol. 47 (2012) 


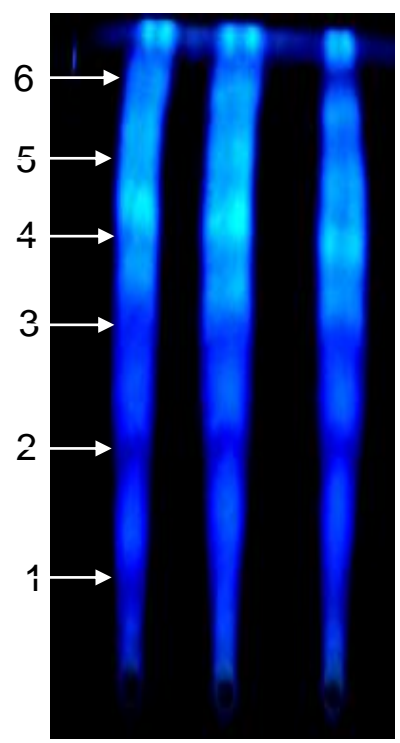

Fig. 1. TLC Profile of the extracted antiviral compounds from Serratia marscecens .

\section{Antioxidant activity}

Total antioxidants concentrations of the plant in response to viral and bacterial treatments were determined by the method of Gupta et al. (2004) with slight modifications by El-Sayed et al. (2012). Briefly, $1 \mathrm{gm}$ of plant leaves was homogenized in a mortar containing $20 \mathrm{ml}$ protein extraction buffer $(50 \mathrm{mM}$ Tris$\mathrm{HCl} \mathrm{pH} \mathrm{7.5,} 20 \mathrm{mM}$ EDTA) with $0.5 \mathrm{~g}$ sterile sea sand. After $10 \mathrm{~min}$ of homogenization in an ice bath, the mixtures were filtered, then the filtrate was centrifuged at $5000 \mathrm{rpm}$ for $10 \mathrm{~min}$. The supernatant was used as the source of antioxidants and intracellular compounds. For antioxidant concentration, $0.5 \mathrm{ml}$ of the plant extract was mixed with $100 \mu \mathrm{l}$ of $20 \mathrm{mM}$ ferrous chloride and $100 \mu \mathrm{l}$ of $30 \%$ ammonium thiocyanate. The developed red complex was measured at $500 \mathrm{~nm}$.

\section{Total soluble protein}

The total soluble protein was determined by the method of Lowry et al. (1951), using bovine serum albumin as standard.

\section{Polyphenol oxidase activity}

Polyphenol oxidase activity was estimated as described by Sarvesh \& Reddy (1988) with slight modifications. Briefly, $200 \mu 1$ of enzyme extract was incubated with $800 \mu \mathrm{l}$ of $0.2 \mathrm{M} \mathrm{O}$-catechol, dissolved in $2 \mathrm{M}$ carbonate- bicarbonate buffer $(\mathrm{pH} 8.0)$, for $30 \mathrm{~min}$ at $30^{\circ} \mathrm{C}$. After stopping of the reaction by addition of $500 \mu \mathrm{l}$ of $5 \% \mathrm{H}_{2} \mathrm{SO}_{4}$, the developed color was measured at $420 \mathrm{~nm}$. One unit of ployphenol oxidase was expressed by the amount of enzyme releasing $1 \mu \mathrm{M}$ of quinine $/ \mathrm{min} / \mathrm{ml}$, under standard assay conditions. 


\section{Glutathione oxidase activity}

Glutathione oxidase activity was determined according to Bergmeyer et al. (1974) with minor modifications. The reaction contains $200 \mu$ l of enzyme preparation with $0.1 \mathrm{M}$ glutathione in potassium phosphate buffer ( $\mathrm{pH} 8.0$ ), 0.2 $\mathrm{mM}$ guaiacol and $2 \mathrm{U}$ horseradish peroxidase. After $30 \mathrm{~min}$ incubation at $30^{\circ} \mathrm{C}$, the reaction was stopped by freezing for $15 \mathrm{~min}$, then the developed color was measured at $436 \mathrm{~nm}$. Glutathione oxidase activity was calculated from the following formula; One unit $=$ A 436/min x 4/25.5 (Extinction co-efficient of tetra-guaiacol).

\section{Phenolic compounds analysis}

Extraction of free and bound cell wall phenols

Free phenols were extracted from cucumber plants according to the method of Campbell \& Ellis (1992). The fresh samples were weighed, then frozen. These samples were powdered in liquid nitrogen using mortar and pestle. The powder was transformed into $5 \mathrm{ml}$ polystrene tubes with caps. Extraction was carried out with 2 vol. of $50 \%$ methanol for $1.5 \mathrm{hr}$. at $80 \pm 1^{\circ} \mathrm{C}$ in a water bath. The mixture was centrifuged for $5 \mathrm{~min}$ at $3000 \mathrm{rpm}$ and the supernatant used for the FolinCiocalteau assays. From the remaining pellets, phenolic acids esterified to the cell wall by ester linkage were saponified for $24 \mathrm{hr}$ at room temperature, according to the method of Funk \& Brodelius (1990), 0.5 M NaOH in the ratio of $1 \mathrm{~g}$ original sample: $4 \mathrm{ml}$. The mixtures were neutralized with one- quarter vol. of $2 \mathrm{M} \mathrm{HCL}$, centrifuged and the supernatants also used for the Folin-Ciocalteau assays according to method described by Julkunen-Tiitto (1985).

\section{RT-PCR deteciton of WMV from Cucumis sativus plants}

Total nucleic acids were extracted from virus infected leaves as described by Yoon \& Ryu (2002), and used as templates for RT-PCR detection. RT was performed in a reaction mixture $(20 \mu \mathrm{l})$ containing $2.5 \mathrm{mM} \mathrm{MgCl} 2,0.5 \mathrm{mM}$ of each dNTP, $1 \mu \mathrm{l}$ containing $50 \mathrm{pM}$ of reverse primer, $1 \times$ buffer, $1 \mathrm{U}$ RNasin (Roche, USA), and $2.5 \mathrm{U}$ SSTII reverse transcriptase (Invitrogen, USA) at $42^{\circ} \mathrm{C}$ for $60 \mathrm{~min}$. PCR was performed using $5 \mu \mathrm{l}$ of the synthesized cDNA, $1 \times$ PCR buffer, $2.5 \mathrm{mM} \mathrm{MgCl}, 0.04 \mathrm{U}$ DNA polymerase Mix Taq (Roche, USA), and $1 \mu \mathrm{l} 50 \mathrm{pM}$ of virus primers (Reverse $5^{\prime}>$ AGATGTTAATCCATGTATACC $<3$ and Forward 5' $>$ GCCAAAACAGCAACGCCA $<3$ ) ( Lee \& Ryu, 2009). PCR was performed in a thermal cycler (BioRad, USA). Denaturation was executed at $94^{\circ} \mathrm{C}$ for $3 \mathrm{~min}$ before starting PCR cycling. Each PCR cycle consisted of $30 \mathrm{~s}$ at $94^{\circ} \mathrm{C}, 30 \mathrm{~s}$ at $52^{\circ} \mathrm{C}$, and $40 \mathrm{~s}$ at $68^{\circ} \mathrm{C}$. A total of 35 cycles was performed, and cycling ended with final extension at $68^{\circ} \mathrm{C}$ for $10 \mathrm{~min}$.

\section{Statistical analysis}

Data of all trials were statistically analyzed using the General Linear Model Program of SAS (1996). Differences among means were tested by Duncan's multiple range test (Duncan, 1955). 


\section{Results}

Screening of antiviral activity of S. marcescens subsp. marcescens on WMV

$S$. marcescens subsp. marcescens showed antiviral activities against WMV on cucumber plants compared to mechanically infected viral control plants. After four weeks under WMV stress, the cucumber plants showed severe symptoms including malformation, stunt, mosaic, dark green blisters and leaf crinkling . Data in Table 1 reveal that the liquid bacterial cultures were the most potent in vitro treatment (100\% viral inhibition), while cell free supernatant (CFS) gave $75 \%$ inhibition of viral infection. (Treatment at $24 \mathrm{hr}$ with liquid. culture was the most effective post inoculation treatment at $90 \%$ viral inhibition). However, cell free supernatant gave 50\% inhibition post viral inoculation by $6 \mathrm{hr}$. Viral infected control plants (mechanically inoculated with WMV) were characterized by mosaic patches, green blistering, leaf curl, malformation and reduction in growth. Moreover, bacterial treated plants not only reduced the symptoms but also improved the plant growth (Photos $1 \& 2$ ) and (Tables $2 \& 3$ ). The liquid culture of $S$. marcescens and its CFS effectively inhibited the production of local lesions on the leaves of Chenopodium amaranticolor compared to untreated leaves, indicating that the bacterium or its secreted metabolites are capable of reducing WMV infection substantially (Photo 3). Also, results in Table 1 showed that soaking of cucumber seeds in liquid culture of $S$. marcescens for $24 \mathrm{hr}$ also was effective in limiting subsequent viral infection ( $85 \%$ reduction) while soaking in CFS for $24 \mathrm{hr}$ gave $70 \%$ viral inhibition.
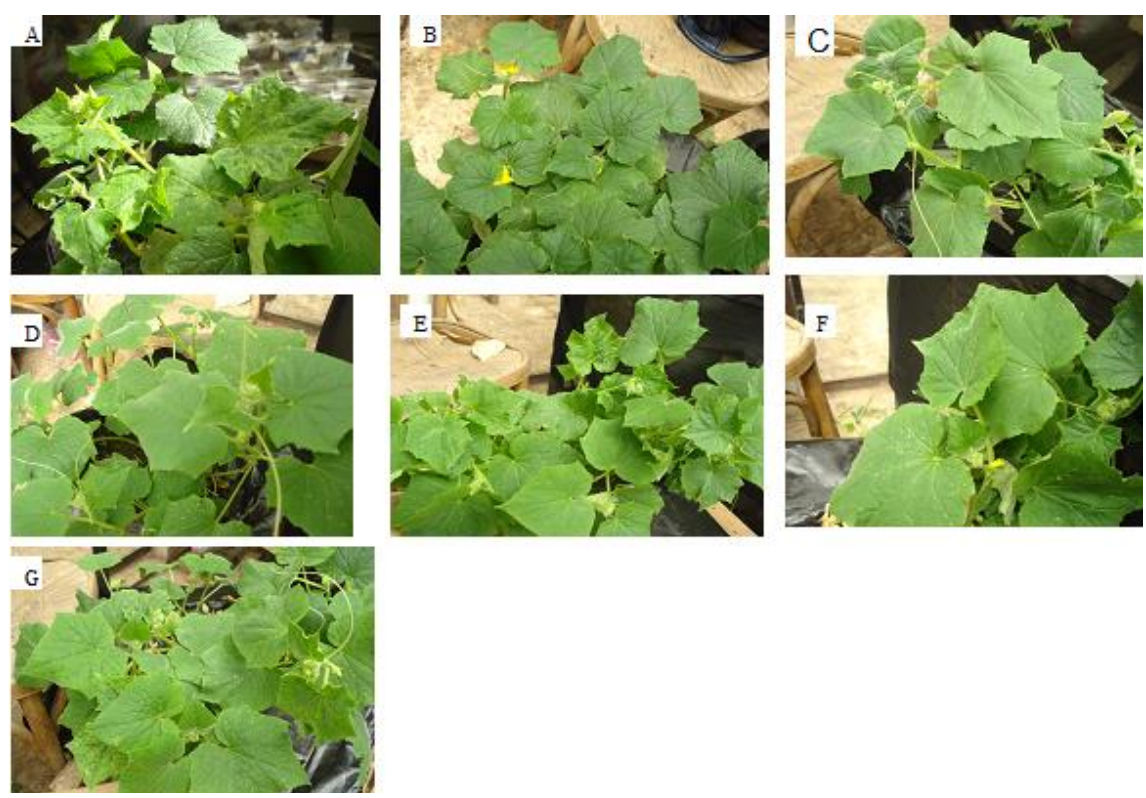

Photo 1. (A) . Viral control; (B): Healthy control; (C): Bacterial control; (D): in vitro bacterial culture; $(\mathrm{E})$ : in vitro bacterial supernatant; (F): post $24 \mathrm{hr}$ bacterial culture; (G): post $24 \mathrm{hr}$ bacterial supernatant. 

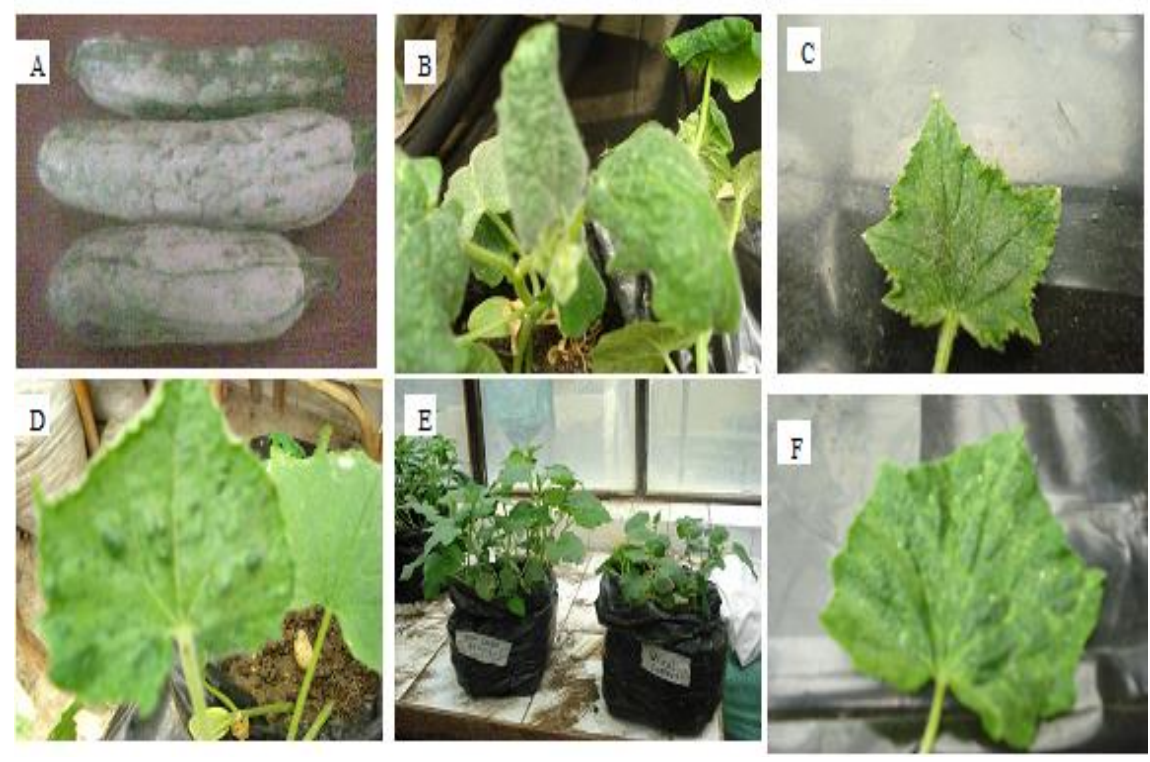

Photo 2. WMV symptoms (A) : Naturally infected squash fruits; (B): Leaf curl; (C): Malformation; (D) Dark green blisters; (E): Reduction in growth; (F): Mosaic.

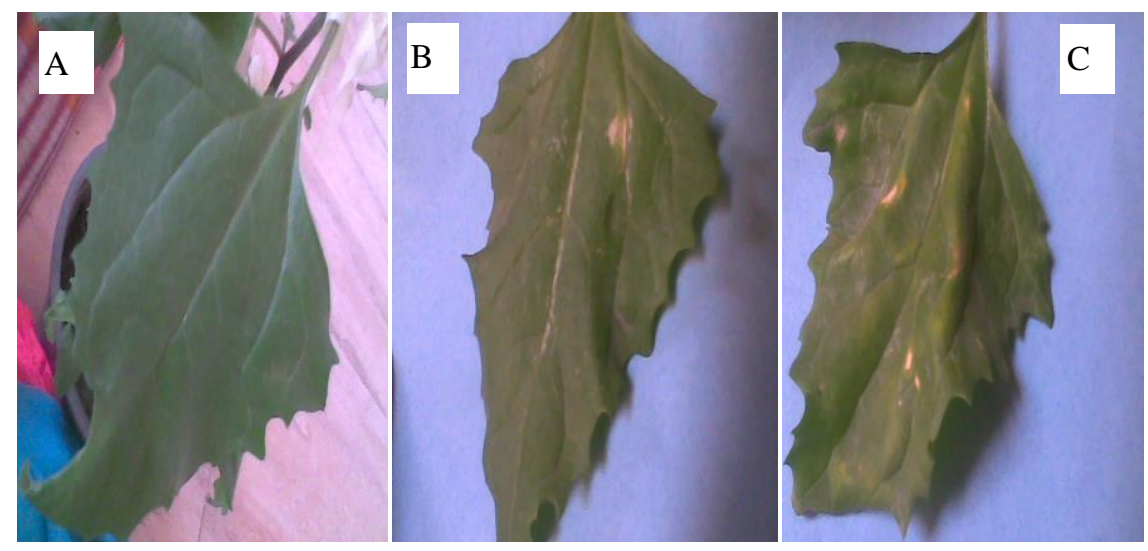

Photo 3. Local lesions (LLs) on the leaves of $C$. amaranticolor by WMV against $S$. marcescens strain ss marcescens. A) The leaves were coated with a mixture of WMV and crude liquid culture of $S$. marcescens. There are no LL. B) the leaves were coated with a mixture of WMV and CFS of $S$. marcescens. One chlorotic LL turned necrotic. C) The leaves were coated with WMV only. There are 14 chlorotic and necrotic $L L$. 
TABLE 1. Effect of liquid bacterial culture and cell free supernatant on the infectivity of watermelon mosaic virus (by \%) on cucumber plants .

\begin{tabular}{|l|c|c|}
\hline \multicolumn{1}{|c|}{ Treatments } & $\begin{array}{c}* \% \text { of viral inhibition by } \\
\text { liquid bacterial culture } \\
\text { of } \text { S. } \text { marcescens }\end{array}$ & $\begin{array}{c}* \% \text { of viral inhibition } \\
\text { by cell free } \\
\text { supernatants of } S \\
\text { marcescens }\end{array}$ \\
\hline $\begin{array}{l}\text { Treatment with bacterial culture } \\
\text { or CFS against WMV (In vitro) }:\end{array}$ & 100 & 75 \\
\hline In vivo, post $6 \mathrm{hr}$ & 57 & 50 \\
\hline In vivo, post $24 \mathrm{hr}$ & 90 & 31 \\
\hline Seed soaking for12 hr & 81 & 65 \\
\hline Seed soaking for $24 \mathrm{hr}$ & 85 & 70 \\
\hline Seed soaking for $36 \mathrm{hr}$ & 60 & 60 \\
\hline
\end{tabular}

General control= twenty plants normal (without any treatments) all are healthy.

Viral control $=$ cucumber seedling mechanically inoculated with WMV on cotyledonary and first stage leaves.

$*=\%$ of viral inhibition $=$ number of symptomatic plants in viral control - number of symptomatic plants in treatment/ number of symptomatic plants in viral control x 100

TABLE 2. Effect of liquid bacterial culture and cell free supernatant of $S$. marcescens on some growth parameters of mechanically infected cucumber plants by WMV. (Each value is the mean for 20 plants \pm SD).

\begin{tabular}{|c|c|c|c|c|}
\hline Treatments & Healthy control & Viral control & $\begin{array}{c}\text { Liquid } \\
\text { bacterial } \\
\text { culture }\end{array}$ & $\begin{array}{c}\text { Cell free } \\
\text { supernatant }\end{array}$ \\
\hline \multicolumn{5}{|c|}{ In vitro } \\
\hline No. of leaves & $5.6 \pm 0.97 \mathrm{a}$ & $3.7 \pm 0.82 \mathrm{~b}$ & $6.1 \pm 0.15 \mathrm{a}$ & $6.2 \pm 0.79 \mathrm{a}$ \\
\hline Shoot length (cm) & $\begin{array}{c}25.1 \pm 3.51 \mathrm{c} \\
\mathrm{a}\end{array}$ & $15.1 \pm 3.14 \mathrm{~d}$ & $30.3 \pm 3.56 \mathrm{~b}$ & $33.5 \pm 3.34 \mathrm{a}$ \\
\hline Fresh weight $(\mathrm{g})$ & $8.94 \pm 0.96 \mathrm{a}$ & $2.96 \pm 1.56 \mathrm{~b}$ & $9.28 \pm 1.92 \mathrm{a}$ & $10.22 \pm 2.12 \mathrm{a}$ \\
\hline \multicolumn{5}{|c|}{ Post experiment $(6 \mathrm{hr})$} \\
\hline No. of leaves & $5.6 \pm 0.97 \mathrm{~b}$ & $3.7 \pm 0.82 \mathrm{c}$ & $5.1 \pm 0.74 \mathrm{~b}$ & $6.5 \pm 1.08 \mathrm{a}$ \\
\hline Shoot length $(\mathrm{cm})$ & $\begin{array}{c}25.1 \pm 3.51 \mathrm{~b} \\
\mathrm{a}\end{array}$ & $15.1 \pm 3.14 \mathrm{~d}$ & $21.5 \pm 2.76 \mathrm{c}$ & $29.8 \pm 3.49 \mathrm{a}$ \\
\hline Fresh weight $(\mathrm{g})$ & $8.94 \pm 0.96 \mathrm{a}$ & $2.96 \pm 1.56 \mathrm{c}$ & $5.97 \pm 0.69 \mathrm{~b}$ & $9.22 \pm 1.67 \mathrm{a}$ \\
\hline \multicolumn{5}{|c|}{ Post experiment $(24 \mathrm{hr})$} \\
\hline No. of leaves & $5.6 \pm 0.97 \mathrm{ab}$ & $3.7 \pm 0.82 \mathrm{c}$ & $6.3 \pm 1.34 \mathrm{a}$ & $5.2 \pm 1.03 \mathrm{~b}$ \\
\hline Shoot length $(\mathrm{cm})$ & $25.1 \pm 3.51 \mathrm{~b}$ & $15.1 \pm 3.14 \mathrm{c}$ & $30.9 \pm 3.34 \mathrm{a}$ & $25.7 \pm 3.59 \mathrm{~b}$ \\
\hline Fresh weight $(\mathrm{g})$ & $8.94 \pm 0.96 \mathrm{ab}$ & $2.96 \pm 1.56 \mathrm{c}$ & $9.73 \pm 1.16 \mathrm{a}$ & $8.06 \pm 1.33 \mathrm{~b}$ \\
\hline
\end{tabular}

Healthy control $=$ twenty plants normal (without any treatments) all are healthy.

Viral control= cucumber seedling mechanically inoculated with WMV on cotyledonary leaves and first stage leaves.

$a, b, c, d$ means in the same row with different superscript differ significantly $(\mathrm{p}<0.05)$. 
TABLE 3. Effect of soaking cucumber seeds for different times in liquid culture of $S$. marcescens or cell free supernatant of those cultures on some growth parameters of treated plants inoculated with WMV at first stage leaf (Each value is the mean twenty reading $\pm \mathrm{SE}$ ) .

\begin{tabular}{|c|c|c|c|c|}
\hline Treatments & Healthy control & Viral control & $\begin{array}{c}\begin{array}{c}\text { Liquid bacterial } \\
\text { culture }\end{array} \\
\end{array}$ & $\begin{array}{c}\text { Cell free } \\
\text { supernatant }\end{array}$ \\
\hline \multicolumn{5}{|c|}{ Soaking for $12 \mathrm{hr}$} \\
\hline No. of leaves & $6.2 \pm 0.79 \mathrm{a}$ & $5.2 \pm 0.77 \mathrm{~b}$ & $6.8 \pm 1.03 \mathrm{a}$ & $7.2 \pm 1.48 \mathrm{a}$ \\
\hline Shoot length $(\mathrm{cm})$ & $39.0 \pm 3.16 \mathrm{a}$ & $28.7 \pm 1.64 \mathrm{~b}$ & $43.5 \pm 4.1 \mathrm{a}$ & $43.0 \pm 8.95 \mathrm{a}$ \\
\hline Fresh weight $(\mathrm{g})$ & $9.77 \pm 1.456 \mathrm{~b}$ & $7.31 \pm 0.93 \mathrm{c}$ & $9.41 \pm 1.52 b$ & $12.04 \pm 2.73 \mathrm{a}$ \\
\hline \multicolumn{5}{|c|}{ Soaking for $24 \mathrm{hr}$} \\
\hline No. of leaves & $6.2 \pm 0.79 a$ & $5.2 \pm 0.77 \mathrm{~b}$ & $6.7 \pm 0.67 \mathrm{a}$ & $6.6 \pm 1.17 \mathrm{a}$ \\
\hline Shoot length $(\mathrm{cm})$ & $39.0 \pm 3.16 \mathrm{~b}$ & $28.7 \pm 1.64 \mathrm{c}$ & $54.1 \pm 4.36 \mathrm{a}$ & $37.6 \pm 4.53 \mathrm{~b}$ \\
\hline Fresh weight $(\mathrm{g})$ & $9.77 \pm 1.456 \mathrm{a}$ & $7.31 \pm 0.93 b$ & $10.44 \pm 1.48 \mathrm{a}$ & $10.15 \pm 1.06 \mathrm{a}$ \\
\hline \multicolumn{5}{|c|}{ Soaking for $36 \mathrm{hr}$} \\
\hline No. of leaves & $6.2 \pm 0.79 \mathrm{~b}$ & $5.2 \pm 0.77 \mathrm{c}$ & $6.0 \pm 0.67 \mathrm{bc}$ & $7.1 \pm 1.45 \mathrm{a}$ \\
\hline Shoot length $(\mathrm{cm})$ & $39.0 \pm 3.16 \mathrm{~b}$ & $28.7 \pm 1.64 \mathrm{c}$ & $46.70 \pm 3.09 \mathrm{a}$ & $40.1 \pm 7.23 \mathrm{~b}$ \\
\hline Fresh weight $(\mathrm{g})$ & $9.77 \pm 1.456 \mathrm{ab}$ & $7.31 \pm 0.93 \mathrm{c}$ & $8.58 \pm 1.51 \mathrm{bc}$ & $11.31 \pm 3.73 \mathrm{a}$ \\
\hline
\end{tabular}

The growth parameters of post inoculation and in vitro experiments

Growth parameters of plants subjected to post inoculation treatment (in vivo) and in vitro treatments (the bacterial culture or CFS was mixed with WMV) are represented in Table 2. Generally, the data reveal that foliar application of bacterial cultures and CFS significantly $(p<0.05)$ increases the growth of plants over virus infected controls. The virus had significantly $(\mathrm{p}<0.05)$ detrimental effects on all growth parameters measured. An unexpected effect is the observation that in vitro treatment with bacterial cultures or filtrates also significantly $(\mathrm{p}<0.05)$ led to increases of shoot length over the healthy control.

Effect of soaking cucumber seeds in liquid culture of S. marcescens and CFS

In this experiment, $S$. marcescens increased seed germination and seedling vigour where the treated plants germinated after 4 days, while untreated germinated after 6 days. The results on the growth parameters of plants in these experiments are shown in Table 3. In each case, the number of leaves, shoot length and fresh weight increased significantly $(\mathrm{p}<0.05)$ more than the viral control. Moreover, soaking the seeds for $24 \mathrm{hr}$ in liquid culture increased the measured growth parameters above those of the healthy control. These results demonstrate that $S$. marcescens in the rhizosphere promote plant growth. 
Phenolic compounds and enzyme activity

The results in Table 4 show that virus infection decreased the total protein and polyphenol oxidase compared to healthy control, while increasing phenolics and glutsthione oxidase. The application of $S$. marcescens in vitro and in vivo increased the total protein, polyphenoloxidase and phenolic compound compared to viral and healthy control while reducing the measured activity of glutathione oxidase.

TABLE 4. The protein profile, enzyme activity and phenolic compounds of cucumber plants treated in vitro and in vivo with $S$. marcesens.

\begin{tabular}{|l|c|c|c|c|}
\hline \multicolumn{1}{|c|}{ Treatments } & Viral control & $\begin{array}{c}\text { Healthy } \\
\text { control }\end{array}$ & $\begin{array}{c}\text { *In vitro } \\
\text { exp. }\end{array}$ & $\begin{array}{c}\text { In vivo post } \\
\mathbf{2 4} \text { hr. }\end{array}$ \\
\hline Measurements & 0.417 & 0.441 & 0.651 & 0.676 \\
\hline $\begin{array}{l}\text { Glutathione oxidase } \\
\text { (U/ml) }\end{array}$ & 6.10 & 5.23 & 3.79 & 5.20 \\
\hline $\begin{array}{l}\text { Polyphenol oxidase } \\
\text { (POx)U/ml }\end{array}$ & 6.17 & 6.75 & 7.23 & 7.74 \\
\hline $\begin{array}{l}\text { Phenolic compounds } \\
\text { cpd (ug/ml) }\end{array}$ & 94.7 & 67.7 & 96.7 & 96 \\
\hline
\end{tabular}

*In vitro: Treatment with bacterial culture or CFS against WMV (in vitro)

\section{Antiviral substances produced by S. marcescens}

The results of extractability of the antiviral substances showed that benzene, ethyl acetate, petroleum ether, chloroform and pentanol, were capable of extracting antiviral compounds from the culture of S. marcescens, while ethyl alcohol, methanol, acetone and diethyl ether were not suitable in the extraction process. The $\mathrm{R}_{\mathrm{f}}$ of the compound $1,2,3,4,5$, and 6 were $0.27,0.44,0.59,0.69$, 0.81 , and 0.93, respectively. All compounds inhibited WMV. Compound 1 was the most potent compound, as it gave $90 \%$ inhibition from equivalently diluted samples. Mixture of all compounds showed $95 \%$ inhibition (Table 5 and Fig. 1).

TABLE 5. Effect of purified bacterial compounds on the infectivity of watermelon mosaic virus (by \%) on cucumber plants .

\begin{tabular}{|l|c|c|}
\hline Treatments & The Rf & $\begin{array}{c}* \% \text { inhibition of viral } \\
\text { infection by compounds of } \boldsymbol{S} . \\
\text { marcescens }\end{array}$ \\
\hline Compound 1 & 0.27 & 90 \\
\hline Compound 2 & 0.44 & 85 \\
\hline Compound 3 & 0.59 & 85 \\
\hline Compound 4 & 0.69 & 70 \\
\hline Compound 5 & 0.81 & 65 \\
\hline Compound 6 & 0.93 & 60 \\
\hline Mixture of all & - & 95 \\
\hline
\end{tabular}

General control= twenty plants normal (without any treatments) all are healthy.

Viral control= cucumber seedling mechanically inoculated with WMV on cotyledonary leaves and first stage leaves.

$*=\%$ of viral inhibition $=$ number of symptomatic plants in viral control - number of symptomatic plants in treatment/ number of symptomatic plants in viral control x 100 


\section{$R T$-PCR quantification of WMV}

From the data of RT-PCR the titre of WMV was reduced by about 62.9 and $39.7 \%$ using $S$. marcescens co-inoculated in vitro or $24 \mathrm{hr}$ post virus inoculation, respectively compared to positive viral controls. This suggests the bacterial treatment has a deleterious effect on the viral structures as protein coat or on virus replication. Or does it mean the bacterium induces host defences that also lower virus replication capacity (Fig. 2).

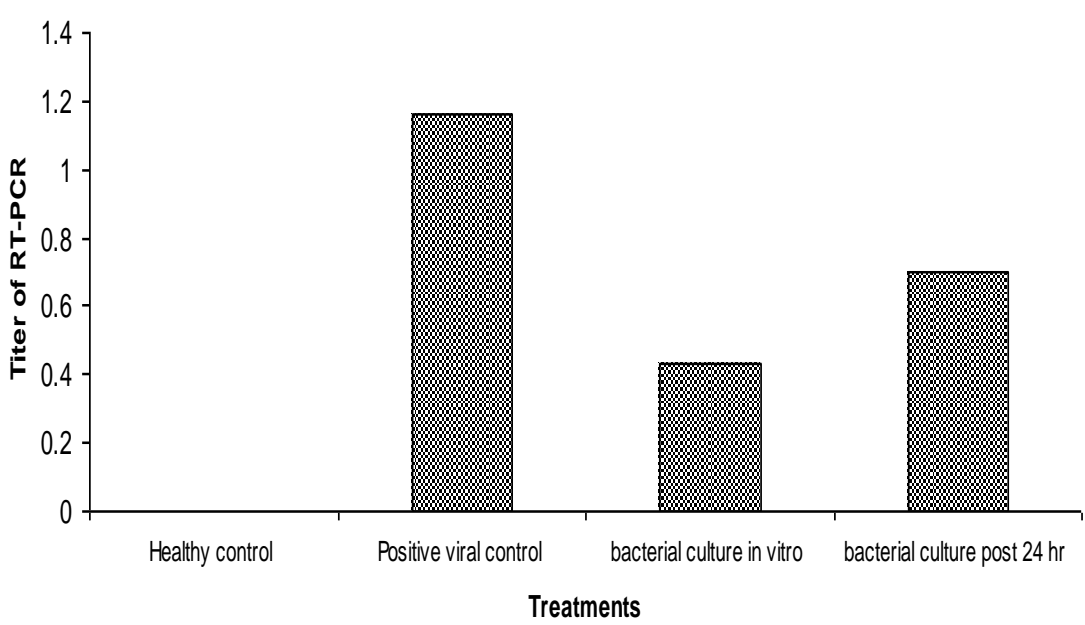

Fig. 2. RT-PCR titer for positive, nega tive and treated plants.

\section{Discussion}

Watermelon mosaic virus (WMV) causes serious economic losses in many cucurbits. Cucurbitaceous crops are grown commercially throughout the world (Yoon et al., 2008). Increasing use of chemical inputs can cause negative effects, such as development of strains of pathogen resistant to the chemical or changes that overcome host resistance genes (Gerhardson, 2002). Furthermore, the growing cost of pesticides and consumer demand for pesticide-free food has led to a search for substitutes for these products. There are also a number of fastidious diseases, e.g., virus \& viroid diseases, for which chemical solutions are few, ineffective or nonexistent (Gerhardson, 2002). Biological control is being considered as an alternative or a supplemental way to reduce the use of chemicals in agriculture (Postma et al., 2003). The present study shows that the crude culture of $S$. marcescens, as well as 6 extracellular products recovered from culture filtrates (CFS) are potent inhibitors of WMV infection. The S. marcescens was used to enhance cucumber growth and protection against WMV infection by foliar spraying and seed soaking; treatment with either liquid culture of $S$. marcescens and its CFS were in harmony with results described by Raupach et al. (1996), Helmy \& Maklad (2003) and Fletcher et al. (2006).

Egypt. J. Microbiol. 47 (2012) 
WMV infection was inhibited up to $100 \%$ when plants were treated simultaneously with a mixture of crude liquid culture + viral sap in vitro for 10 min (foliar treatment). The liquid culture of $S$. marcescens and its CFS inhibited the production of local lesions on the leaves of Chenopodium amaranticolor effectively when compared to untreated leaves, indicating that $S$. marcescens is capable of preventing WMV infection. These results agree with those obtained by Thapa et al. (2009), where they found that culture filtrate of $S$. marcescens strain Gsm01 is a potent inhibitor to CMV-Y on a Chenopodium amaranticolor and on $N$. tobacum cv. Xanthi-nc plants. Treatment of $S$. marcescens crude culture or its CFS $24 \mathrm{hr}$ after WMV inoculation in cucumber plants educed symptoms formation up to $90 \%$ and $31 \%$, respectively as compared to the viral control plants. This could be due to some form of induced systemic resistance.

Results here are in accordance with previous studies, where Maurhofer et al. (1994) successfully studied the resistance effect of $P$. fluorescens on tobacco against TNV. Also, the PGPR strains of Serratia spp. have been reported to mediate induced systemic resistance (ISR) in protection against CMV infection (Raupach et al., 1996; Ryu et al., 2004 and Thapa et al., 2009).

Seeds soaked with crude culture or CFS for $24 \mathrm{hr}$ showed WMV infection reductions of 85 and $70 \%$, respectively and also led to increases in several growth parameters of cucumber plants (number of leaves, shoot length and fresh weight). Increases were significant $(\mathrm{p}<0.05)$ in comparison to virus infected control plants. These results agree with those of Shehata \& El-Borollosy (2008) who showed that $S$. marcescens crude culture treatment inhibited ZYMV if present for $72 \mathrm{hr}$ at germination or prevented infection for $72 \mathrm{hr}$ and enhanced the growth of squash plants. Investigators studied the effect of PGPR on plant growth when used in the form of biofertilizer which is mainly attributed to: i) Fixation of atmospheric nitrogen, ii) Solubilization of minerals such as phosphorus, and iii) Synthesis of phytohormones (Murphy et al., 2003; Lucas Garcia et al., 2004 and Han et al., 2005).

The RT-PCR technique is highly sensitive and is considered a reliable method for quantifying virus presence in comparison with biological indexing. RT-PCR became widely used as a diagnostic method for detecting infecting plant viruses for several different groups, such as the geminiviruses, luteoviruses and potyviruses (Al-Saleh et al., 2010). Data shown in this study represent the inhibition of WMV infection based on number of asymptomatic plants and RTPCR diagnosis. In the present study RT-PCR confirmed that not all of plants giving negative external symptoms were virus-free, as it gives reading in virus amplification. These results revealed that virus replication was inhibited with bacterial treatment, but still some virus particles were present. These results agree with previous study, e.g. Shehata \& El-Borollosy (2008).

Using gel electrophoresis, a new protein band $(22.4 \mathrm{KDa})$ was detected in treated cucumber plants and it may be a signal for induced systemic resistance in 
plants (data not shown). This results agree with that obtained by Abdel-Shafi (2005) and Shehata \& El-Borollosy (2008).

Extracts of virus infected plants had decreased total protein and polyphenoloxidase compared to healthy controls, but increased levels of phenolic compounds and glutathione oxidase. These results are similar to Zinati (2009) who showed total protein reduction and increases in phenolic compounds in Matvdaht infected with wheat streak mosaic virus. The loss of leaf soluble protein in viral infected leaves may be due to either degenerated chloroplasts or inhibition porotein synthesis (Bertamini et al., 2005). The usage of S. marcescens in vitro and in vivo increased the total protein, polyphenoloxidase and phenolic compound compared to viral and untreated healthy control plants, while reducing the glutathione oxidase. These results may indicate that plants respond to infection by synthesis of phenolic compounds to prevent proliferation and spreading of virus as part of an active defense response (Nicholson \& Hammerschmidt, 1992). Also, bacterial treatments increase the phenolic compounds more than viral control emphasize the role of phenolic compounds in preventing movement and reducing symptoms on plants.

Acknowledgement: The authors wish to thank Dr. Ashraf El-Sayed, Botany Department, Faculty of Science, Zagazig University for helping to analysis of antioxidants.

\section{References}

Abd El-Shafi, S. (2005) Biological studies on antiviral activities of some bacterial isolates, Ph.D. Thesis, Dept. of Bot. Microbiol., Fac. of Science., Zag. Univ., Egypt.

Al-Saleh, M.A., Al-Shahwan, I.M., Abdalla, O.A. and Amer, M.A. (2010) Identification and coat protein nucleotide sequence of turnip mosaic potyvirus from Eruca sativa in Saudi Arabia. Asian J. Plant Pathol. 4, 116-127.

Bergmeyer, H.U., Gawehn, K. and Grassl, M. (1974) In: "Methods of Enzymatic Analysis", Bergmeyer Hu (Ed.) Vol. 1. Academic Press, New York, pp. 495-496.

Bertamini, M., Malossini, U., Muthuchelian, K. and Nedunchezhian, N. (2005) Physiological response of field grown Grapevine (Vitis vinifera L. cv. Marzemino) to Grapevine learoll-associated virus(GLRaV-1). Phytopathlogia Mediterranea, 44, 256265 .

Campell, M.M. and Ellis, B.E. ( 1992) Fungal elicitor- mediated responses in Pine cell cultures. Planta, 186, 409-417.

Desbiez, C., Costa, C., Wipf- Scheibel, C., Girard, M. and Lecoq, H. (2007) Serological and molecular variability of watermelon mosaic virus (genus Potyvirus) Arch. Virol. 152, 775-781.

Difco Manual (1994) "Dehydrated Culture Media and Reagents for Microbiology". $10^{\text {th }}$ ed. Difco Lab., USA.

Duncan, D.B. (1955) Multiple ranges and multiple F tests. Biometrics, 11, 1-42.

Egypt. J. Microbiol. 47 (2012) 
El-Sayed, A.S, Shindia, A.A. and Zaher, Z. (2012) L-Amino Acid Oxidase from Filamentous Fungi: Screening and Optimization. Annals Microbiol DOI: 10.1007/s13213-011-0318-2.

Faccioli, G. and Capponi, R. (1983) An antiviral factor present in plants of Chenopodium amaranticolor locally infected by tobacco necrosis virus: 1- Extraction, partial purification, biological and chemical properties. Phytopathol, 106, 289-301.

Fletcher, J., Bender, C., Budowle, B., Cobb, W.T., Gold, S.E, Ishimaru, C.A., Melcher, D., Murch, R., Scherm, H., Seem, R.C., Sherwood, J.L., Sobral, B.W. and Tolin, S.A. (2006) Plant pathogen forensics: Capabilities, needs and recommendation. Microbiol Mol Rev.70, 450-471.

Funk, C. and Brodelius, P.E. (1990) Phenylpropanoid metabolism in suspension cultures of Vanilla planifolia Andr. II. Effects of precursor feeding and metabolic inhibitors. Plant Physiol. 94, 95-101.

Gerhardson, B. (2002) Biological substitutes for pesticides. Trends Biotechnol. 20, 338343.

Giri, A.V., Anandkumar, N., Muthukumaran, G. and Pennathaur, G. (2004) A novel medium for enhanced cell growth and production of prodigiosin from Serratia marcescens isolated from soil. BMC Microbiol. 4, 4-11.

Gupta, M., Mazumdar, U.K., Gomathi, P. and Kumar, R.S. (2004) Antioxidant and free radical scavenging activities of Ervatamia coronaria Stapf leaves. Iran. J. Pharm. Res. 2, 119-126.

Han, J., Sun, L., Dong, X., Cai, Z., Sun, X., Yang, H., Wang, Y. and Song,W. (2005) Characterization of a novel plant growth-promoting bacteria strain Delftia tsuruhatensis HR4 both as a diazotroph and a potential biocontrol agent against various plant pathogen. Syst. Appl. Microbiol. 28, 66-76.

Hausbeck, M.K. (2011) Watermelon mosaic virus detected in winter squash. MSU (Michigan State University) Extension News p.1-2.

Hejazi, A. and Falkiner, F.R. (1997) Serratia marcescens . J. Med. Microbiol. 46, 903912.

Helmy, Y.I. and Maklad, F.M. (2003) Induced systemic resistance against cucumber mosaic virus using biotic inducers on cucumber plants and its effect on yield under plastic houses. Egypt. J. Appl Sci. 18, 287-305.

Julkunen-Tiitto, R. (1985) Phenolics constituents in the leaves of northeren willows: methods for the analysis of certain phenolics. J. Agr. Food. Chem. 33, 213-217.

Laemmli, U.K. (1970) Cleavage of structural proteins during the assembly of the head of bacteriophage T4. Nature (London), 227, 680-685.

Lee, B.Y. and Ryu, K. H. (2009) Incidence of virus diseases and RT-PCR detection of Daphne-infecting viruses in Korea. Eur. J. Plant Pathol. 124, 127-132. 
Lowry, O.H., Rosebrough, N.J., Farr, A.L. and Randall, R.J. (1951) Protein measurements with the Folin phenol reagent. J. Biological Chem. 193, 265-275.

Lucas Garcia, J.A., Probanza, A., Romas,B., Barriuso,J. and Gutierrez Manero,F.J. (2004) Effect of inoculation with plant growth promoting rhizobacteria (PGPRs) and Sinorhizobium fredii on biological nitrogen, fixation, nodulation and growth of Glycine max cv. Osumi. Plant and Soil, 267, 143-153.

Maurhofer, M., Hase, C., Meuwly, P., Metraux , J.P. and Defago, G. ( 1994) Induction of systemic resistance of tobacco to tobacco necrosis virus by the root colonizing Pseudomonas fluorescens strai CHAO : Influence of gacA gene and of pyoverdine production. Phytopathol. 84, 139-146.

Murphy, J.F. and Zehnder, G.W. (2000) Plant growth promoting rhizobacterial mediated protection in tomato against tomato mottle virus. Plant Dis. 84, 784-799.

Murphy, J.F., Reddy, M.S., Ryu, C.M., Kloepper, J.W.and Li, R. (2003) Rhizobacteramediated growth promotion of tomato leads to protection against cucumber mosaic virus. Phytopathol. 93, 1301-1307.

Nichlson, R.L. and Hammerschmidt, R. (1992) Phenolic compounds and their role in disease resistance. Ann. Rev. Phytopath. 30, 369-389.

Palukaitis, P., Roossinck, M.J., Dietzgen, R.G. and Francki, R.I.B. (1992) Cucumber mosaic virus. Adv. Virus. Res. 41, 281- 348.

Postma, J., Montanari, M. and Van den Boogert, P.H.J.F. (2003) Microbial enrichment to enhance the disease suppressive activity of compost. Eur. J. Soil Biol .39, 157-163.

Purcifull, D.E., Hiebert, E. and Edwardson, J. (1984) Description of plant viruses, No. 293.

Raupach, G.S., Liu, L., Murphy, J.F. and Klocpper, J.W. (1995) Biological control of cucumber mosaic cucumovirus in Cucumis sativus L., by PGPR- mediated induced systemic resistance (Abst.), Phytopathol. 85, 1167.

Raupach, G.S., Liu, L., Murphy, J.F.,Tuzun, S. and Klocpper, J.W. (1996) Induced systemic resistance in cucumber and tomato against cucumber mosaic cucumovirus using plant growth promoting rhizobacteria (PGPR). Plant Dis. 80, $891-894$.

Ryu, C.M., Murphy, J.F., Mysore, K.S. and Kloepper, J.W. (2004) Plant growthpromoting rhizobacteria systemically protect Arabidopsis thalina against cucumber mosaic virus by a salacilic acid and NPRI-independant and jasmonic acid -dependant signaling pathway. Plant J. 39, 381-392.

Sarvesh, A. and Reddy, T.P. (1988) Peroxidase, polyphenol oxidase, acid phosphatase and alkaline inorganic pyrophosphatase activities during leaf senescence in varieties of castor (Ricinus communis L.). Indian J. Exp. Biol. 26, 133-136.

SAS $^{\circledR}$ (1996) User`s Guide: Statistics, version 6. $12^{\text {th }}$ edition. SAS inst. Inc., Cary, NC. 
Sharma, N.K., Awasthi, L.P. and Singh, S.k. (2010) Biophysical properties of the watermelon mosaic virus-1 causing mosaic in watermelon. J. Phytol. 2, 21-24.

Shehata, S.F.and El-Borollosy, A.M. (2008) Induction of resistance against zucchini yellow mosaic potyvirus and growth enhancement of squash plants using some plant growth-promoting rhizobacteria. Australian J. Basic Appl. Sci. 2, 174-182.

Shukla, D.D., Ward, C.W. and Brunt, A.A. (1994) The Potyviridae. Wallingford, UK: $C A B$ International, 516.

Thapa, S.P., Lee, H.J., Park, D.H., Kim, S.K., Cho,J.M., Cho, S., Hur, J.H. and Lim, C.K. (2009) Antiviral effects of the culture filtrate from Serratia marcescens Gsm01, against cucumber mosaic virus (CMV). Plant Pathol. J. 25, 369-375.

Ulhoq, J. and Peberdy, J.F. (1991) Regulation of chitinase synthesis in Trichoderma harzinum. J. General Microbiol. 137, 2163- 2169.

Webb, R.E. and Scott, H.S. (1965) Isolation and identification of watermelon mosaic virus 1 and 2. Phytopathol. 55, 895-900.

Yarwood, C.E. (1955) Mechanical transmission of apple mosaic virus. Hilgardia, 23

Yoon, H. I. and Ryu, K. H. (2002) Molecular identification and sequence analysis of Ornithogalum mosaic virus from Iris plants. The Plant Pathol. J. 18, 251-258.

Yoon, J.Y., Choi, G.S., Choi, S.K., Hong, J.S. and Choi, J.K. (2008) Molecular and biological diversities of Cucumber green mottle mosaic virus from cucurbitaceous crops in Korea. J. Phytopathol. 156, 408-412.

Zinati, Z. (2009) The effect of temperature on biochemical changes in inoculation peroid in resistant and susceptible bread wheat genotypes to wheat steak mosaic virus. M.Sc.Thesis. Shiraz University, Shiraz, Iran. 


\section{التأثيرات الضد فيروسية للمزرعة السائلة و العالثق بلون

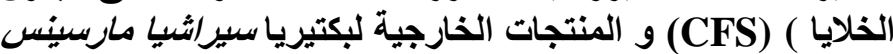

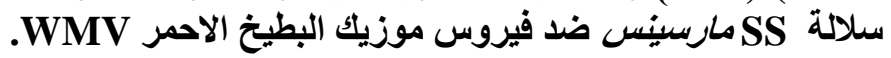

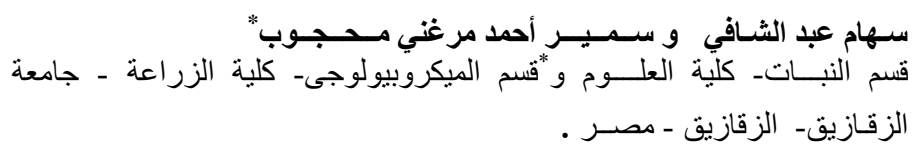

تم در اسة التأثير ات الضد فيروسية للمزر عة السائلة و CFS و المنتجات الخيات الخارجية

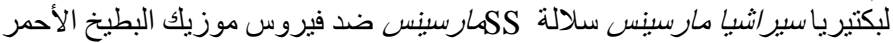

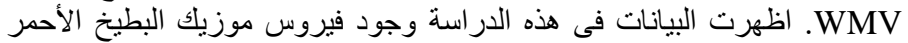

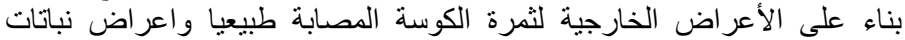

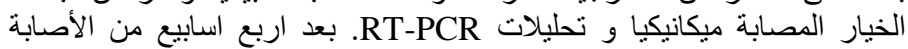

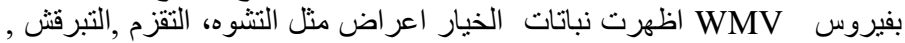

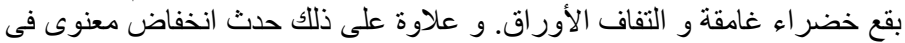

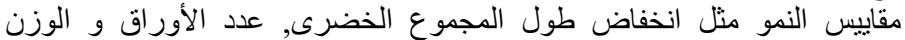

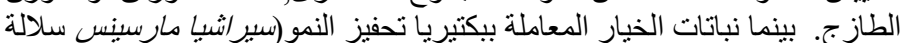
SمSSS

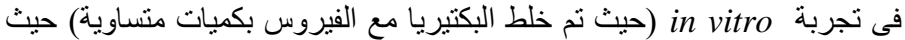

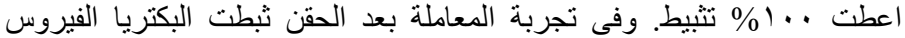

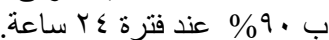

عند نقع بذور الخيار فى المزرعة السائلة و CFS للبكتريا زاد الأنبات و ثبط

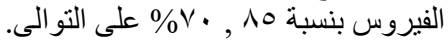

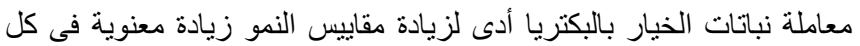
التجارب مقارنة بالنباتات المصابة بالفيروس ( الكنترول) ل

تم استخلاص و تتقية 7 مو اد ضد فيروسية من البكترياو اختبار الانشطة الضد

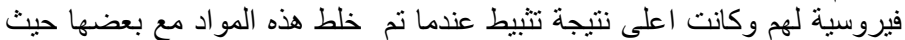
اعطت 90\% تثبيط

واوضحت نتائج RT-PCR ان معاملة البكتريا لنباتات الخيار فى تجربتى in vitro, post 24 h

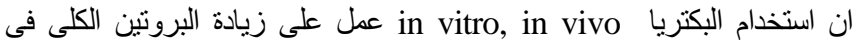

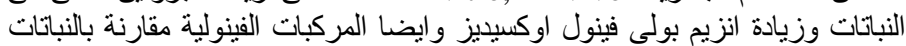
المصابة بالفيروس فقط و النباتات السليمة بينما انخفض ولنئ انزيم glutathione. 